\title{
The Pd-catalyzed Copper-free Carbonylative Sonogashira Reaction of Aryl lodides with Alkynes for the Synthesis of Alkynyl Ketones and Flavones by Using Water as a Solvent
}

\author{
Supporting Information
}

\section{Table of Content:}

Page 2: $\quad$ General Information and General procedure for the carbonylative Sonogashira coupling in water

Page 2-6: $\quad{ }^{1} \mathrm{H}$ NMR and ${ }^{13} \mathrm{C}$ NMR data for compounds $\mathbf{1 a - 1} \mathbf{j}$ and $\mathbf{2 a - 2 j}$.

Page 6: $\quad$ General procedure for synthesis of flavone

Page 6-9: $\quad{ }^{1} \mathrm{H}$ NMR and ${ }^{13} \mathrm{C}$ NMR for compounds 3a-3i.

Page 9-10: General procedure for synthesis of idiophenols 


\section{General Information}

All reagents were used as received and used directly without further purification. Silica gel (200-300) for purification and silica gel TLC $\left(\mathrm{F}_{254}\right)$ were purchased from Qing Dao Hai Yang Chemical Industry Co. of China.

${ }^{1} \mathrm{H}$ NMR spectra were recorded on a Varian Inova $300 \mathrm{MHz}$ spectrometer. ${ }^{13} \mathrm{C}$ NMR spectra were recorded on a Varian Inova $75 \mathrm{MHz}$ spectrometer. Mass spectra were obtained on a ZAB-HS (EI, 70eV) spectrometer.

\section{General procedure for the carbonylative Sonogashira coupling in water}

To a $25 \mathrm{~mL}$ of Schlenk tube equipped with a magnetic stirring bar were added $\mathrm{PdCl}_{2}$ (17.7mg, 0.1 mmol), $\mathrm{PPh}_{3}$ (52.4mg, 0.2mmol), 4-idioanisole (468mg, 2mmol), and $2.5 \mathrm{~mL} \mathrm{H}_{2} \mathrm{O}$, and then $\mathrm{Et}_{3} \mathrm{~N}(0.84 \mathrm{~mL}, 6 \mathrm{mmol})$ was injected into the tube. The mixture was first stirred for five minutes, and then 1 -hexyne $(0.28 \mathrm{~mL}, 2.4 \mathrm{mmol})$ was added to the tube. The reaction mixture was stirred at room temperature for 12 hours under a balloon pressure of CO. The mixture was extracted with ethyl acetate $(5 \times 5$ $\mathrm{mL}$ ), and the combined organic layers were dried over $\mathrm{Na}_{2} \mathrm{SO}_{4}$. The solvent was removed under vacuum, and the residue was purified by flash chromatography (hexane/ethyl acetate $=40 / 1)$ to give product $1 \mathrm{a}(410 \mathrm{mg}$ ) in $95 \%$ yield as a colorless oil.

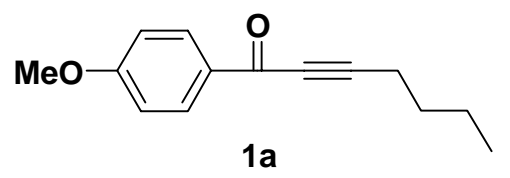

Solvent system for flash chromatography (hexane:ethyl acetate $=40 / 1$ ), and the product yield is $95 \%$ as a colorless oil. The spectroscopic data please see reference: Yadav, J. S. Reddy; B. V. S.; Reddy, M. Sridhar; Parimala, G. Synthesis, 2003, 15, 2390-2394.)

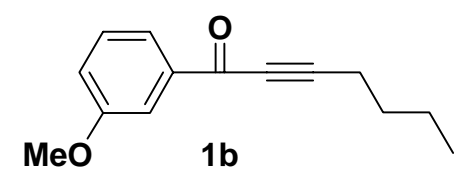

Solvent system for flash chromatography (hexane/ethyl acetate $=80 / 1$ ), and the product yield is $90 \%$ as a colorless oil. The spectroscopic data please see reference: Annabelle L. K. Shi Shun, Erin T. Chernick, Sara Eisler, and Rik R. Tykwinski, J. Org. Chem. 2003, 68, 1339-1347.

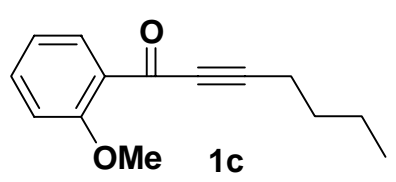

Solvent system for flash chromatography (hexane:ethyl acetate $=20: 1$ ), the product yield is $90 \%$ yield as a colorless oil. ${ }^{1} \mathrm{H}$ NMR $\left(300 \mathrm{MHz}, \mathrm{CDCl}_{3}\right): \delta 0.95(\mathrm{t}, 3$ 
$\mathrm{H}), 1.44-1.52$ (m, $2 \mathrm{H}), 1.58-1.65(\mathrm{~m}, 2 \mathrm{H}), 2.46(\mathrm{t}, 2 \mathrm{H}), 3.91$ (s, $3 \mathrm{H}), 6.97-7.04$ (m, 2 $\mathrm{H}), 7.48-7.54(\mathrm{~m}, 1 \mathrm{H}), 8.00-8.03(\mathrm{~m}, 1 \mathrm{H}) ;{ }^{13} \mathrm{C} \mathrm{NMR}\left(75 \mathrm{MHz}, \mathrm{CDCl}_{3}\right): \delta 13.5,18.9$, 21.9, 29.77, 55.7, 81.7, 95.3, 111.9, 120.0, 126.7, 132.9, 134.6, 159.5, 177.1; MS $\left[\mathrm{C}_{14} \mathrm{H}_{16} \mathrm{O}_{2}\right]$, (EI) $\mathrm{m} / \mathrm{z}\left(\mathrm{M}^{+}\right)$, calcd 216, found 216 .

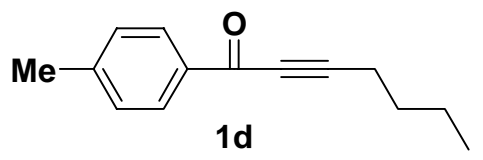

Solvent system for flash chromatography (hexane:ethyl acetate $=50 / 1$ ), and the product yields is $95 \%$ yield as a colorless oil. The spectroscopic data please see reference: Ma, D.; Lin, Y.; Lu, X.; Yu, Y. Tetrahedron Lett. 1988, 29, 1045-1048.)

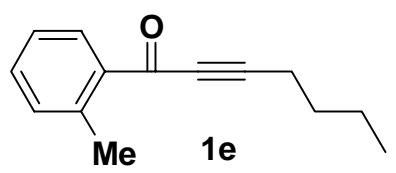

Solvent system for flash chromatography (hexane/ethyl acetate $=80 / 1$ ), and the yield for isolated product is $90 \%$ as a colorless oil. ${ }^{1} \mathrm{H}$ NMR $\left(300 \mathrm{MHz}, \mathrm{CDCl}_{3}\right): \delta$ 0.95 (t, 3 H), 1.45-1.52 (m, 2 H), 1.59-1.66 (m, 2 H), 2.47 (t, 2 H), 2.62 (s, 3 H), 7.21$7.24(\mathrm{~m}, 1 \mathrm{H}), 7.31-7.34(\mathrm{~m}, 1 \mathrm{H}), 7.40-7.42(\mathrm{~m}, 1 \mathrm{H}), 8.19-8.21(\mathrm{~m}, 1 \mathrm{H}) ;{ }^{13} \mathrm{C} \mathrm{NMR}$ (75MHz, $\left.\mathrm{CDCl}_{3}\right): \delta 13.5,18.8,21.9,22.0,29.8,81.1,95.4,125.7,131.9,132.6,133.2$, 135.7, 140.3, 179.9; $\mathrm{MS}\left[\mathrm{C}_{14} \mathrm{H}_{16} \mathrm{O}\right],(\mathrm{EI}) \mathrm{m} / \mathrm{z}\left(\mathrm{M}^{+}\right)$, calcd 200, found 200.

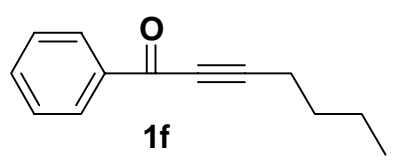

The solvent for flash chromatography (hexane:ethyl acetate $=80 / 1$ ), and yield for the isolated product is $93 \%$ as a colorless oil. The spectroscopic data please see reference: Mary M. Jackson; Carolyn Leverett; Jennifer F. Toczko; John C. Roberts, J. Org. Chem. 2002, 67, 5032-5035.)

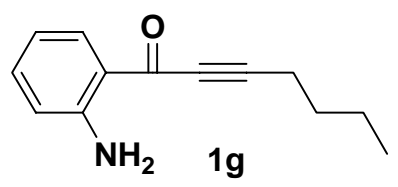

The solvent system for flash chromatography (hexane:ethyl acetate $=40 / 1$ ), and the yield for the purified product is $85 \%$ as a pale yellow oil. ${ }^{1} \mathrm{H}$ NMR $(300 \mathrm{MHz}$, $\left.\mathrm{CDCl}_{3}\right): \delta 0.94(\mathrm{t}, 3 \mathrm{H}), 1.44-1.51(\mathrm{~m}, 2 \mathrm{H}), 1.58-1.65(\mathrm{~m}, 2 \mathrm{H}), 2.46(\mathrm{t}, 2 \mathrm{H}), 6.37(\mathrm{~s}$, $2 \mathrm{H})$, 6.61-6.69 (m, $2 \mathrm{H})$, 7.24-7.29 (m, $1 \mathrm{H}), 8.06-8.08(\mathrm{~m}, 1 \mathrm{H}) ;{ }^{13} \mathrm{C}$ NMR $(75 \mathrm{MHz}$, $\left.\mathrm{CDCl}_{3}\right): \delta 13.4,18.7,21.9,29.7,79.7,95.7,115.7,116.6,118.6,134.4,134.9,150.9$, 179.8; MS [ $\left.\mathrm{C}_{13} \mathrm{H}_{15} \mathrm{NO}\right],(\mathrm{EI}) \mathrm{m} / \mathrm{z}\left(\mathrm{M}^{+}\right)$, calcd 201, found 201. 


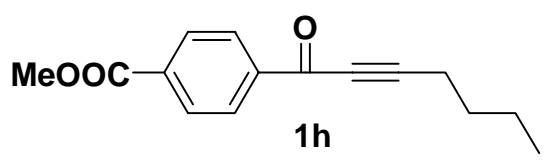

The solvent system for flash chromatography (hexane:ethyl acetate $=20 / 1$ ), and the yield for the purified product is $46 \%$ as a colorless oil. The spectroscopic data please see reference: Tseng, J.; Huang, S.; Lin, C.; Lin, H.; Jin, B.; Chen, C.; Yu, J.; Chou, P.; Luh, T. Org. Lett. 2003, 5, 4381-4384.)

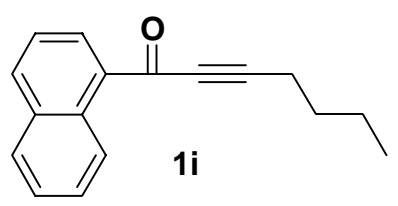

The solvent system for flash chromatography (hexane/ethyl acetate $=40 / 1$ ), and the yield for the purified product is $80 \%$ as a colorless oil. ${ }^{1} \mathrm{H}$ NMR $(300 \mathrm{MHz}$, $\left.\mathrm{CDCl}_{3}\right): \delta 0.94(\mathrm{t}, 3 \mathrm{H}), 1.44-1.51(\mathrm{~m}, 2 \mathrm{H}), 1.58-1.65(\mathrm{~m}, 2 \mathrm{H}), 2.46(\mathrm{t}, 2 \mathrm{H}), 7.48$ $7.53(\mathrm{~m}, 2 \mathrm{H}), 7.59-7.64(\mathrm{~m}, 1 \mathrm{H}), 7.82-7.85(\mathrm{~m}, 1 \mathrm{H}), 7.98-8.01(\mathrm{~m}, 1 \mathrm{H}), 8.50-8.53$ $(\mathrm{m}, 1 \mathrm{H}), 9.18-9.21(\mathrm{~m}, 1 \mathrm{H}) ;{ }^{13} \mathrm{C} \mathrm{NMR}\left(75 \mathrm{MHz}, \mathrm{CDCl}_{3}\right): \delta 13.4,18.7,21.9,29.7$, 81.1, 95.1, 124.2, 125.8, 126.5, 128.4, 128.6, 130.5, 132.8, 133.6, 134.3, 134.7, 179.8; MS $\left[\mathrm{C}_{17} \mathrm{H}_{16} \mathrm{O}\right],(\mathrm{EI}) \mathrm{m} / \mathrm{z}\left(\mathrm{M}^{+}\right)$, calcd 236, found 236 .

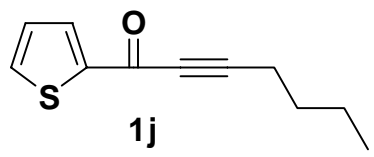

The solvent system for flash chromatography (hexane/ethyl acetate $=40 / 1$ ), and the yield for the purified product is $71 \%$ as a pale yellow oil. The spectroscopic data please see reference: Annabelle L. K. Shi Shun, Erin T. Chernick, Sara Eisler, and Rik R. Tykwinski, J. Org. Chem. 2003, 68, 1339-1347.)

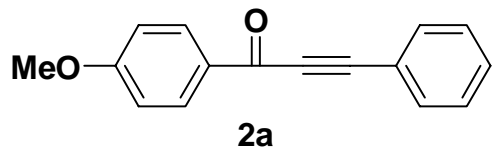

The solvent system for flash chromatography (hexane:ethyl acetate $=20 / 1$ ), and the yield for the purified product is $87 \%$ as a colorless solid. The spectroscopic data please see reference: Ahmed, M.; Mori, M. S. A. Org. Lett. 2003, 5, 3057.)

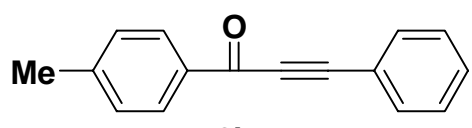

2b

Solvent system for flash chromatography (hexane:ethyl acetate $=20 / 1$ ), and 
yield for the purified product is $80 \%$ as a colorless solid. The spectroscopic data please see reference: Mohamed Ahmed, M. S.; Mori, A. Org. Lett. 2003, 5, 3057.)

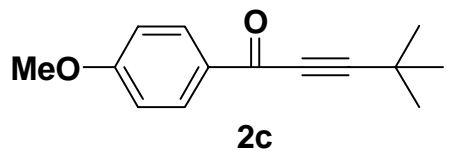

The solvent system for flash chromatography (hexane/ethyl acetate $=20 / 1$ ), and the yield for the purified product is $95 \%$ as a colorless oil. The spectroscopic data please see reference: Mohamed Ahmed, M. S.; Mori, A. Org. Lett. 2003, 5, 3057.)

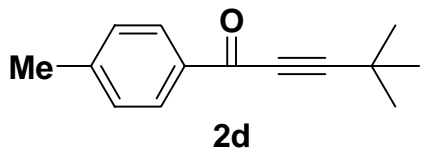

The solvent system for flash chromatography (hexane:ethyl acetate $=40 / 1$ ), and the yield for the purified product is $96 \%$ as a colorless oil. The spectroscopic data please see reference: Kang, S.; Ryu, H.; Hong, Y. J. Chem. Soc. Perkin Trans. 1. 2001, 7, 736739.)

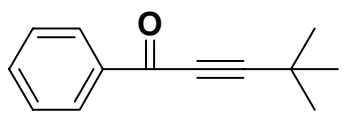

$2 e$

The solvent system for flash chromatography (hexane:ethyl acetate $=40 / 1$ ), and the yield for the purified product is $90 \%$ as a colorless oil. The spectroscopic data please see reference: Mohamed Ahmed, M. S.; Mori, A. Org. Lett. 2003, 5, 3057.)

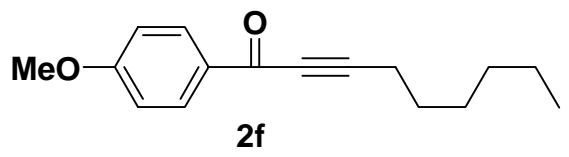

The solvent system for flash chromatography (hexane:ethyl acetate $=80 / 1$ ), and the yield for the purified product is $92 \%$ as a colorless oil. The spectroscopic data please see reference: Mohamed Ahmed, M. S.; Mori, A. Org. Lett. 2003, 5, 3057.)

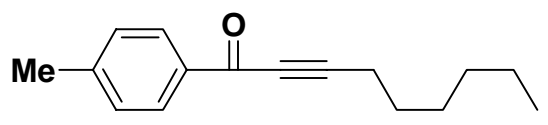

$2 \mathrm{~g}$

The solvent system for flash chromatography (hexane:ethyl acetate $=40 / 1$ ), and the yield for the purified product is $90 \%$ as a colorless oil. The spectroscopic data please see reference: Mohamed Ahmed, M. S.; Mori, A. Org. Lett. 2003, 5, 3057.) 


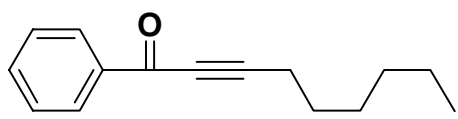

$2 \mathrm{~h}$

The solvent system for flash chromatography (hexane:ethyl acetate $=80 / 1$ ), and the yield for the purified product is $93 \%$ as a colorless oil. The spectroscopic data please see reference: Alonso, D. A.; Najera, C.; Carmen Pacheco, M. J. Org. Chem. 2004, 69, 1615-1619.)

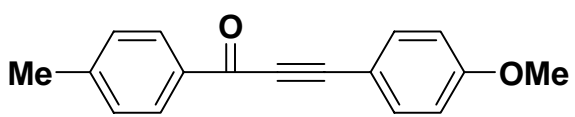

2i

Solvent system for flash chromatography (hexane:ethyl acetate $=20 / 1$ ), and the yield for the purified product is $92 \%$ as a colorless solid. The spectroscopic data please see reference: Kang, S.; Ryu, H.; Hong, Y. J. Chem. Soc. Perkin Trans. 1. 2001, 7, 736739.)

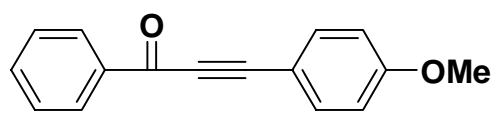

2j

Solvent system for flash chromatography (hexane:ethyl acetate $=20 / 1$ ), and the yield for the purified product is $60 \%$ as a colorless solid. The spectroscopic data please see reference: Kang, S.; Ryu, H.; Hong, Y. J. Chem. Soc. Perkin Trans. 1. 2001, 7, 736739.)

\section{General procedure for synthesis of flavone:}

To a $25 \mathrm{~mL}$ of Schlenk tube equipped with a magnetic stirring bar were added $\mathrm{PdCl}_{2}$ (17.7 mg, $0.1 \mathrm{mmol}$ ), $\mathrm{PPh}_{3}$ (52.4 mg, $0.2 \mathrm{mmol}$ ), 2-idiophenol (440 mg, 2.0 $\mathrm{mmol})$ and $\mathrm{H}_{2} \mathrm{O}(2.5 \mathrm{~mL})$, and then $\mathrm{Et}_{3} \mathrm{~N}(0.84 \mathrm{~mL}, 6.0 \mathrm{mmol})$ was injected into the tube. After stirring for five minutes, 1-hexyne $(0.28 \mathrm{~mL}, 2.4 \mathrm{mmol})$ was added to the tube, and the mixture was stirred under a balloon pressure of $\mathrm{CO}$ for $12 \mathrm{~h}$. The reaction mixture was extracted with ethyl acetate $(4 \times 5 \mathrm{~mL})$, and the combined organic phases were dried over $\mathrm{Na}_{2} \mathrm{SO}_{4}$. The solvent was removed under vacuum and the residue was purified by flash chromatography (hexane/ethyl acetate $=8 / 1$ ) to give the product 3a $(368 \mathrm{mg})$ in $91 \%$.<smiles>CCCCc1cc(=O)c2ccccc2o1</smiles>

3a 
Solvent system for flash chromatography (hexane:ethyl acetate $=8: 1$ ), and the yield for the purified product is $91 \%$ yield. The spectroscopic data please see reference: Milewski, M.; Urjasz, W.; Maciejewski, A.; Augustyniak, W. Pol. J. Chem. 1998, 72, 2405-2417.)<smiles>CC(C)(C)c1cc(=O)c2ccccc2o1</smiles>

Solvent system for flash chromatography (hexane:ethyl acetate = 20:1), and the yield for the purified product is $47 \%$ yield. The spectroscopic data please see reference: Engbersen, J. F. J.; Koudijs, A.; Plas, H. C. Van der, J. Heterocycl. Chem. 1982, 19, 1281-1283.)<smiles>O=c1ccoc2ccccc12</smiles>

2 equivalence TMS-acetylene was employed in this reaction. The solvent system for flash chromatography (hexane:ethyl acetate $=8: 1$ ), and the yield for the purified product is 55\%. The spectroscopic data please see reference: Lin, Q.; Leong, W. K. organometallics, 2003, 22, 3639-3648.)

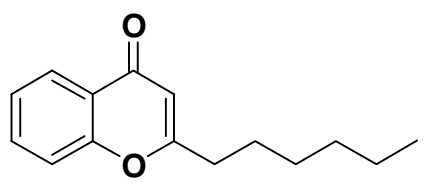

3d

Solvent system Purification by flash chromatography (hexane:ethyl acetate $=$ $8: 1$ ), and the yield for the purified product is $70 \%$ yield. The spectroscopic data please see reference: Bonini, B. F.; Carboni, P.; Gottarelli, G.; Masiero, S.; Spada, G. P. J. Org. Chem. 1994, 59, 5930-5936.)

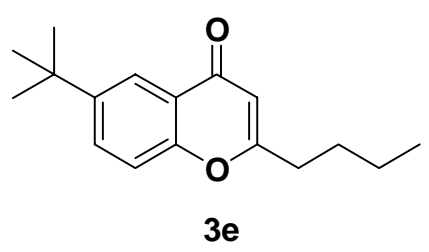

Solvent system for flash chromatography (hexane/ethyl acetate $=8: 1$ ), and the yield for the purified product is $70 \%$ yield. ${ }^{1} \mathrm{H} \mathrm{NMR}\left(300 \mathrm{MHz}, \mathrm{CDCl}_{3}\right): \delta 0.92-0.98$ $(\mathrm{m}, 3 \mathrm{H}), 1.37-1.46(\mathrm{~m}, 11 \mathrm{H}), 2.61(\mathrm{t}, 2 \mathrm{H}), 6.17(\mathrm{~s}, 1 \mathrm{H}), 7.37(\mathrm{~d}, J=9.0 \mathrm{~Hz}, 1 \mathrm{H})$, $7.70\left(\mathrm{dd}, J_{l}=9.0 \mathrm{~Hz}, J_{2}=2.4 \mathrm{~Hz}, 1 \mathrm{H}\right), 8.18(\mathrm{~d}, J=2.4 \mathrm{~Hz}, 1 \mathrm{H}) ;{ }^{13} \mathrm{C}$ NMR $(75 \mathrm{MHz}$, 
$\left.\mathrm{CDCl}_{3}\right): \delta 13.6,21.9,28.7,31.2,33.8,34.6,109.5,117.3,121.2,122.8,131.1,147.9$, 154.5, 169.4, 178.5; MS [ $\left.\mathrm{C}_{17} \mathrm{H}_{22} \mathrm{O}_{2}\right]$, (EI) $\mathrm{m} / \mathrm{z}\left(\mathrm{M}^{+}\right)$, calcd 258, found 258.<smiles>CCCCc1cc(=O)c2cc(C)ccc2o1</smiles>

Solvent system for flash chromatography (hexane/ethyl acetate $=8: 1$ ), and the yield for the purified product is $78 \%$ yield. ${ }^{1} \mathrm{H} \mathrm{NMR}\left(300 \mathrm{MHz}, \mathrm{CDCl}_{3}\right): \delta 0.95(\mathrm{t}, 3$ $\mathrm{H}), 1.37-1.45(\mathrm{~m}, 2 \mathrm{H}), 1.64-1.74(\mathrm{~m}, 2 \mathrm{H}), 2.40(\mathrm{~s}, 3 \mathrm{H}), 2.58(\mathrm{t}, 2 \mathrm{H}), 6.13(\mathrm{~s}, 1 \mathrm{H})$, 7.27-7.30 (m, $1 \mathrm{H}), 7.39-7.42(\mathrm{~m}, 1 \mathrm{H}), 7.93(\mathrm{~s}, 1 \mathrm{H}) ;{ }^{13} \mathrm{C} \mathrm{NMR}\left(75 \mathrm{MHz}, \mathrm{CDCl}_{3}\right): \delta$ 13.3, 20.4, 21.7, 28.4, 33.5, 109.0, 117.1, 122.8, 124.4, 134.1, 134.2, 154.2, 169.1, 177.8; MS $\left[\mathrm{C}_{14} \mathrm{H}_{16} \mathrm{O}_{2}\right],(\mathrm{EI}) \mathrm{m} / \mathrm{z}\left(\mathrm{M}^{+}\right)$, calcd 216, found 216 .

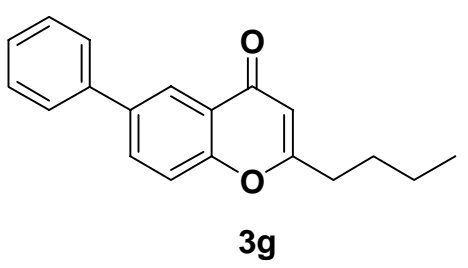

Solvent system for flash chromatography (hexane/ethyl acetate $=20: 1$ ), and the yield for the purified product is $95 \% .{ }^{1} \mathrm{H} \mathrm{NMR}\left(300 \mathrm{MHz}, \mathrm{CDCl}_{3}\right): \delta 0.97(\mathrm{t}, 3 \mathrm{H})$, 1.40-1.47 (m, 2 H), 1.68-1.78 (m, 2 H), 2.62 (t, 2 H), 6.20 (s, 1 H), 7.34-7.50 (m, 4 H), 7.63-7.66 (m, $2 \mathrm{H}), 7.85-7.88(\mathrm{~m}, 1 \mathrm{H}), 8.40(\mathrm{~s}, 1 \mathrm{H}) ;{ }^{13} \mathrm{C} \mathrm{NMR}\left(75 \mathrm{MHz}, \mathrm{CDCl}_{3}\right): \delta$ 13.7, 22.0, 28.7, 33.9, 109.7, 118.3, 123.4, 123.7, 127.0, 127.7, 128.8, 132.2, 137.9, 139.3, 155.8, 169.8, 178.3; MS [ $\left.\mathrm{C}_{19} \mathrm{H}_{18} \mathrm{O}_{2}\right]$, (EI) m/z (M $\mathrm{M}^{+}$, calcd 278, found 278 .<smiles>CCCCc1cc(=O)c2cc(Cl)ccc2o1</smiles>

Solvent system for flash chromatography (hexane/ethyl acetate $=20: 1$ ), and the yield for the purified product is $90 \% .{ }^{1} \mathrm{H} \mathrm{NMR}\left(300 \mathrm{MHz}, \mathrm{CDCl}_{3}\right): \delta 0.97(\mathrm{t}, 3 \mathrm{H})$, 1.40-1.47 (m, 2 H), 1.67-1.75 (m, 2 H), 2.63 (t, 2 H), 6.17 (s, $1 \mathrm{H})$, 7.37-7.40 (m, $1 \mathrm{H})$, 7.54-7.58 (m, $1 \mathrm{H}), 8.11(\mathrm{~d}, J=2.4 \mathrm{~Hz}, 1 \mathrm{H}) ;{ }^{13} \mathrm{C} \mathrm{NMR}\left(75 \mathrm{MHz}, \mathrm{CDCl}_{3}\right): \delta 13.6,21.9$, $28.6,33.8,109.5,119.5,124.5,124.8,130.6,133.4,154.6,170.0,176.9$; MS $\left[\mathrm{C}_{13} \mathrm{H}_{13} \mathrm{ClO}_{2}\right],(\mathrm{EI}) \mathrm{m} / \mathrm{z}\left(\mathrm{M}^{+}\right)$, calcd 236, found 236 . 


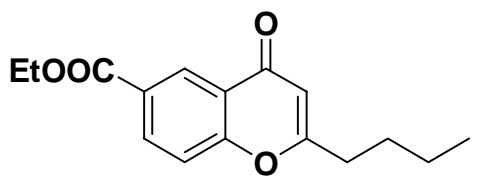

$3 \mathbf{i}$

Solvent system flash chromatography (hexane/ethyl acetate $=8: 1$ ), and the yield for the purified product is $35 \%$ yield. ${ }^{1} \mathrm{H} \mathrm{NMR}\left(300 \mathrm{MHz}, \mathrm{CDCl}_{3}\right): \delta 0.98(\mathrm{t}, 3$ H), 1.40-1.47 (m, 5 H), 1.72-1.77 (m, 2 H), 2.65 (t, 2 H), 6.21 (s, $1 \mathrm{H}), 7.48$ (d, $J=8.7$ $\mathrm{Hz}, 1 \mathrm{H}), 8.31\left(\mathrm{dd}, J_{l}=8.7 \mathrm{~Hz}, J_{2}=2.1 \mathrm{~Hz}, 1 \mathrm{H}\right), 8.86(\mathrm{~d}, J=2.1 \mathrm{~Hz}, 1 \mathrm{H}) ;{ }^{13} \mathrm{C} \mathrm{NMR}$ $\left(75 \mathrm{MHz}, \mathrm{CDCl}_{3}\right): \delta 13.7,14.3,22.1,28.7,33.9,61.4,110.1,118.2,123.3,127.2$, 127.9, 134.1, 158.8, 165.3, 170.0, 177.7; MS [C $\left.{ }_{16} \mathrm{H}_{18} \mathrm{O}_{4}\right]$, (EI) $\mathrm{m} / \mathrm{z}\left(\mathrm{M}^{+}\right)$, calcd 274, found 274

General procedure for synthesis of idiophenols (the idiophenols were prepared according to the literature: Kevin J. Edgar and Stephen N. Falling, J. Org. Chem. 1990, $55,5287-5291$.

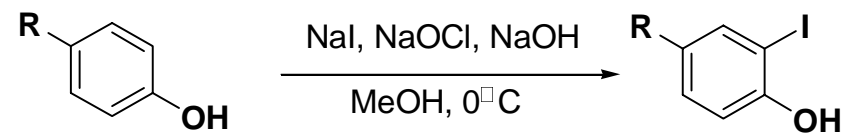<smiles>CC(C)(C)c1ccc(O)c(I)c1</smiles>

The spectroscopic data please see reference: Crisp, G. T.; Bubner, T. P. Tetrahedron 1997, 53, 11881-11898.)<smiles>Cc1ccc(O)c(I)c1</smiles>

The spectroscopic data please see reference: Holzapfel, C. W.; Bradley, D.; Williams, G. Tetrahedron 1995, 51, 8555-8564.)<smiles>Oc1ccc(-c2ccccc2)cc1I</smiles>

The spectroscopic data please see reference: Edgar, K. J.; Falling, S. N. J. Org. Chem. 1990, 55, 5287-5291.) 


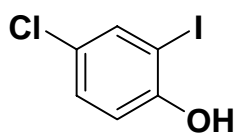

The spectroscopic data please see reference: Edgar, K. J.; Falling, S. N. J. Org. Chem. 1990, 55, 5287-5291.)

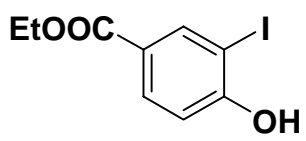

The spectroscopic data please see reference: Kadnikov, D. V.; Larock, R. C. J. Org. Chem. 2003, 68, 9423-9432.) 